\title{
İstanbul'daki Yüzme Havuzu Suları ve Biyofilm Örneklerinde Legionella ve Serbest Yaşayan Amiplerin Görülme Sıklığının Farklı Yöntemlerle Araştırılması
}

\section{Investigation of the Incidence of Legionella and Free-Living Amoebae in Swimming Pool Waters and Biofilm Specimens in Istanbul by Different Methods}

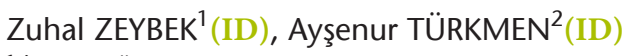 \\ 1 İstanbul Üniversitesi Fen Fakültesi, Biyoloji Bölümü, Temel ve Endüstriyel Mikrobiyoloji Anabilim Dalı, İstanbul. \\ ${ }^{1}$ Istanbul University Faculty of Science, Department of Biology, Department of Fundamental and Industrial Microbiology, \\ Istanbul, Turkey. \\ 2 i̇stanbul Üniversitesi, Fen Bilimleri Enstitüsü, İstanbul. \\ 2 Istanbul University, Institute of Graduate Studies in Science and Engineering, Istanbul, Turkey.
}

\footnotetext{
* Bu çalışma, istanbul Üniversitesi Bilimsel Projeler Birimi tarafından desteklenmiştir (Proje no: 9269).

** Bu çalışma, "1 $1^{\text {st }}$ International Symposium on Graduate Research in Science Focus on entrepreneurship and innovation (ISGRS 2018)" Sempozyumu (4-6 Ekim 2018)'nda sunulmuştur.
}

Makale Atıfı: Zeybek Z, Türkmen A. Istanbul'daki yüzme havuzu suları ve biyofilm örneklerinde Legionella ve serbest yaşayan amiplerin görülme sıklığının farklı yöntemlerle araştırılması. Mikrobiyol Bul 2020;54(1):50-65.

\section{ÖZ}

Serbest halde yaşayan ya da biyofilmde bulunan Legionella cinsi bakteriler ve serbest yaşayan amipler (SYA), yüzme havuzları aracılığıyla insanlara bulaşıp çeşitli hastalıklara neden olabilmektedir. SYA, ayrıca Legionella ve diğer bazı bakteriler için konak olma yeteneğinde oldukları için de yüzücülerin sağlığını tehdit edebilmektedir. Bu çalışmada, İstanbul'daki yüzme havuzu suları ve biyofilm örneklerinde toplam aerobik heterotrofik bakteriler (TAHB), SYA ve Legionella bakterilerinin varlığının kültür ve floresan in situ hibridizasyon (FISH) yöntemleri kullanılarak araştııılması amaçlanmıştır. TAHB, Legionella ve SYA'nın kültürü için sırasıyla "water plate count agar (WPCA)", glisin-vankomisin-polimiksin-sikloheksimit (GVPC) eklenmiş "buffered charcoal yeast extract (BCYE)" agar, Escherichia coli ekilmiş "non-nutrient agar (NNA)" kullanılmıştır. FISH yöntemiyle analiz amacıyla Legionella için floresan boya ile işaretli Leg 705 ve Leg PNE1 probları, Acanthamoeba cinsi SYA için ACANTHA probu kullanılmıştır. Pozitif kontrol olarak Legionella pneumophila serogroup 1 ATCC 33152, L.pneumophila serogroup 3 ATCC 33155, Acanthamoeba castellani ATCC 50373 suşları kullanılmıştır. Su ve biyofilm örneklerinin $\% 92$ ve $\% 84$ 'ünde TAHB üretilmiştir. Su örneklerinin hiçbirinde Legionella bakterileri üretilemediği halde, FISH yöntemiyle $6(\% 24)$ su örneğinde bakteri tespit edilmiştir. Bu bakteriler biyofilm örneklerinin 1 (\%4)'inde üretilebildiği halde FISH yöntemiyle 7 (\%28)'sinde tespit edilmiştir. SYA, su örneklerinde kültürle \%16, FISH analiziyle \%28 
oranında saptanmıştır. Bu amipler, biyofilm örneklerinde, kültür ve FISH yöntemiyle sırasıyla \%8 ve \%24 oranında tespit edilmiştir. İzole edilen bir SYA izolatının termotoleran aktiviteye sahip (potansiyel patojen) olduğu bulunmuştur. Bir su ve dört biyofilm örneğinde L.pneumophila serogrup 1 varlığı tespit edilmiştir. Kültür yöntemine göre, TAHB ve SYA'ya su örneklerinde biyofilm örneklerindekine göre daha fazla, Legionella cinsi bakterilere ise biyofilm örneklerinde su örneklerindekine göre daha fazla oranda rastlandığı tespit edilmiştir $(p \leq 0.05)$. Legionella cinsi bakterilerin tespitinde FISH yönteminin kültür yöntemine göre üstün olduğu istatistiksel olarak anlamlı bulunmuştur $(p \leq 0.05)$. Bu çalışma ile denetimi yapılan yüzme havuzlarında TAHB sayısının Sağlık Bakanlığının belirlediği sınırlar içerisinde $(\leq 200$ $\mathrm{kob} / \mathrm{ml}$ ) olduğu saptanmıştır. TAHB, SYA ve Legionella tespitinde hem su hem de biyofilm örneklerinin incelenmesi yerinde olacaktır. Gerek su gerekse biyofilm örneklerindeki SYA'nın varlığının tespiti için kültür ve FISH yöntemlerinin her ikisinin de kullanılması uygun olabilir. Bu çalışma, İstanbul'daki yüzme havuzlarında Legionella ve SYA'ların varlığının araştırıldığı ilk çalışma olup daha fazla sayıda havuz suyu ve biyofilm örneklerinin inceleneceği yeni çalışmalara gereksinim bulunmaktadır. Elde edilecek veriler sayesinde yüzme havuzlarının sağlık esasları ve denetimleri yeniden ele alınıp, halk sağlığına katkı sağlanabilecektir.

Anahtar kelimeler: Yüzme havuzu suyu; biyofilm; Legionella; serbest yaşayan amipler; FISH.

\section{ABSTRACT}

Legionella bacteria living in free form or in biofilm and free-living amoebae (FLA) can infect humans through swimming pools and can cause various diseases. FLA may also threaten the health of swimmers because they are capable of being hosts for Legionella and some other bacteria. The aim of this study was to investigate the presence of total aerobic heterotrophic bacteria (TAHB), FLA and Legionella bacteria in swimming pool waters and biofilm samples in Istanbul by using culture and FISH methods. Water plate count agar (WPCA), buffered charcoal yeast extract (BCYE) agar supplemented with glycinevancomycin-polymyxin-cycloheximide (GVPC) and Escherichia coli cultivated non-nutrient agar (NNA) were used for the culture of TAHB, Legionella and FLA. For the FISH method analysis, Leg 705 and Leg PNE1 probes labeled with fluorescent dye for Legionella and ACANTHA probe for Acanthamoeba genus FLA were used. Legionella pneumophila serogroup 1 ATCC 33152, L.pneumophila serogroup 3 ATCC 33155 and Acanthamoeba castellani ATCC 50373 were used as positive controls. TAHB were grown in $92 \%$ and $84 \%$ of water and biofilm samples. Although Legionella bacteria could not be grown in any of the water samples, it was detected in $6(24 \%)$ water samples by FISH method. Although these bacteria could be grown in 1 (4\%) of biofilm samples, 7 (28\%) were detected by FISH method. FLA were found to be $16 \%$ by culture in water samples and $28 \%$ by FISH analysis. These amoebae were detected $8 \%$ and $20 \%$ in biofilm samples by culture and FISH method, respectively. It was determined that one of the isolates of FLA had thermotolerant activity (potentially pathogenic). L.pneumophila serogroup 1 was detected in one water sample and in four biofilm samples. According to the culture method, TAHB and FLA were found to be more common in water samples than in biofilm samples and Legionella bacteria were more common in biofilm samples than in water samples $(p \leq 0.05)$. In the detection of Legionella bacteria, the superiority of FISH method compared to culture method was found to be statistically significant $(p \leq 0.05)$. In this study, it was found that the number of TAHB in the controlled swimming pools was within the limits determined by the Ministry of Health $(\leq 200 \mathrm{cfu} / \mathrm{ml})$. It will be appropriate to examine both water and biofilm samples for the investigation of TAHB, FLA and Legionella. It may be appropriate to use both culture and FISH methods to detect the presence of FLA in water and biofilm samples. This study is the first study to investigate the presence of Legionella and FLA in swimming pools in Istanbul, and further studies are needed to examine more pool water and biofilm samples. With the data obtained, the health principles and controls of swimming pools will be re-considered and will be contributed to public health.

Keywords: Swimming pool waters; biofilm; Legionella; free-living amoeba; FISH. 


\section{Gíriş}

Yüzme havuzları, sitelerde, özel konutlarda, okullarda, spor salonlarında gerek spor gerekse eğlence amacıyla tüm dünyada olduğu gibi ülkemizde de yoğun olarak yüzücüler tarafından kullanılmaktadır. Bakımı, temizliği ve dezenfeksiyonu iyi yapılmadığı takdirde yüzme havuzları birçok mikroorganizmanın kaynağı haline gelip, insanlarda birçok hastalığa neden olabilmektedir. Havuz sularında yaşayan mikroorganizmalar, zamanla havuz cidarında, derz aralarında, havuz içi sirkülasyonun oluşmadığı ölü bölgelerde, kum filtrelerinin içinde vb. biyofilm tabakası da oluşturarak dezenfeksiyonda büyük sorunların oluşmasına yol açabilirler ${ }^{1}$.

Ülkemizde yüzme havuzlarında uyulması gereken sağlık esasları ve şartları T.C. Sağlık Bakanlı̆̆ı tarafından 6 Mart 2011 tarihinde T.C. Resmi Gazete'de yayımlanan yönetmelik ile bildirilmiştir. Bu esaslar, kimyasal ve fiziksel parametrelerin yanı sıra, toplam aerobik heterotrofik bakteri (TAHB), toplam koliform bakteri, Escherichia coli ve Pseudomonas aeruginosa için belirlenmiş değerler ile mikrobiyolojik parametreleri içermektedir ${ }^{2} .2015$ yılında Ulusal Havuz Enstitüsü tarafından Legionella bakterilerinin de önemi belirtilerek, $100 \mathrm{ml}$ havuz suyunda hiç bulunmaması gerektiği yazılı olarak bildirilmiştir ${ }^{3}$. Legionella cinsi bakteriler içerisinde özellikle Legionella pneumophila aerosol halde suyun solunmasıyla bulaşan ve pnömoniyle seyreden ciddi enfeksiyonlar oluştururlar ${ }^{4}$. Ayrıca serbest yaşayan amipler (SYA), Legionella cinsi bakterileri hücrelerinin içerisine alabilir ve böylece onları dış ortamın olumsuz koşullarından korur, bakteriler ise SYA içerisinde çoğalıp, şartlar uygun hale geldiğinde amip hücrelerini parçalayarak sayılarını da artırmış olarak dış ortama yayılabilirler ${ }^{5-7}$. SYA hem bu yetenekleri hem de su ile insanlara bulaşarak granülomatöz amibik ensefalit (GAE), keratit gibi çeşitli hastalıklara neden olma yetenekleri sayesinde bilim insanlarının oldukça ilgisini çekmektedir ${ }^{7}$.

Bu çalışmada, İstanbul'daki yüzme havuzlarından alınan hem su hem de biyofilm örneklerinde TAHB, Legionella cinsi bakteriler ve SYA'nın varlığı/sayıları kültüre dayalı ve kültüre dayalı olmayan yöntemler kullanılarak araştırılması amaçlanmıştır.

\section{GEREÇ ve YÖNTEM}

Bu çalışmada, i̇stanbul'da altısı açık, 19'u kapalı olan 25 adet yüzme havuzundan alınan su ve biyofilm örnekleri mikrobiyolojik açıdan incelendi (Resim 1). Örneklerin alınması sırasında termometre (Isolab, ölçüm aralığı $-20 /+50$ ) kullanılarak su sıcaklıkları, Chembio (Bilge kimyevi Lab., Türkiye) klor ve pH kitleriyle, üretici firmanın önerileri doğrultusunda kolorimetrik yöntemle, serbest klor ve pH değerleri ölçüldü. Örneklerin alınması aşamasında sıklıkla havuz işletmelerindeki yetkili kişilerin engellemeleriyle karşılaşıldı. Bakırköy Belediyesi Çevre Koruma ve Kontrol Birimi çalışanlarının desteği ile denetim amacıyla örnek aldıkları takvime uyularak (dokuz havuz için) aynı anda örneklem toplandı.

\section{Örneklerin Toplanması}

Yüzme havuzu sularından SYA'nın ve TAHB'nin analizi için 500'er ml'lik steril cam şişeler, Legionella cinsi bakterilerin analizi için 3000 ml'lik steril plastik bidonlar kullanıldı. 


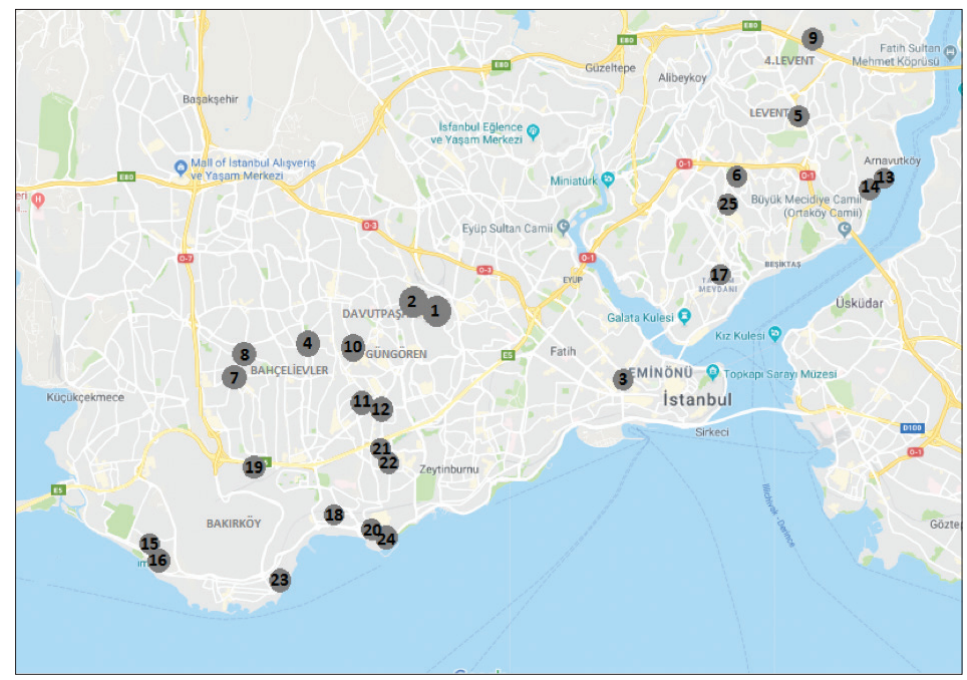

Resim 1. Istanbul'da örnek alınan yüzme havuzlarının bulunduğu bölgeler.

Su numuneleri T.C. Sağlık Bakanlığı havuz suyu yönetmeliğinde belirtildiği gibi havuz kenarının $50 \mathrm{~cm}$ ötesinden ve su yüzeyinin $20 \mathrm{~cm}$ altından, şişeler tamamen doldurulmak suretiyle alındı ${ }^{2}$. Örneklerin alınmasından önce havuz suyunda bulunan klorun nötralizasyonu amacıyla örnek kaplarının içerisine $0.5 \mathrm{ml} / \mathrm{L} \% 0.5^{\prime}$ lik sodyum tiyosülfat eklendi ${ }^{8}$.

Aynı yüzme havuzlarına ait biyofilm örnekleri havuz cidarının $10 \mathrm{~cm}^{2 \prime}$ lik alanından steril eküvyon yardımıyla alınıp içerisinde $10 \mathrm{ml}$ steril çeşme suyu bulunan santrifüj tüpü içerisine koyularak en kısa zamanda laboratuvara ulaştırıldı ${ }^{9}$. Alınan tüm örnekler, kültür ve floresan in situ hibridizasyon (FISH) yöntemine göre incelenmek amacıyla, güneş ışığına maruz bırakılmadan $5^{\circ} \mathrm{C}^{\prime}$ de en kısa zamanda laboratuvara ulaştırıldı.

\section{Mikrobiyolojik Kültür Yöntemi}

Toplam aerobik heterotrofik bakteri kültürü: Laboratuvara getirilen su örnekleri $0.45 \mu \mathrm{m}$ por çaplı steril membran filtre ve çelik filtre sistemi (Sartorius, Almanya) kullanılarak yoğunlaştırıldı. Biyofilm örnekleri iki dakika "stomacher" (IUL Instruments, 120 sn/50 hz) cihazında tutuldu ve sonra bir dakika vortekslendi. Örneklerde TAHB'lerin kültürü için "water plate count agar (WPCA)" besiyeri kullanıldı. Tüm besiyerleri $22^{\circ} \mathrm{C}^{\prime}$ de 72 saat, $37^{\circ} \mathrm{C}^{\prime}$ de 48 saat inkübasyona bırakıldı. Plaklarda üreyen bakteri kolonileri sayılarak kaydedildi. Tüm kültürler üç kez tekrar edilerek çalışıldı ${ }^{10}$.

Serbest yaşayan amip kültürü: Laboratuvara getirilen su örnekleri $0.45 \mu \mathrm{m}$ por çaplı steril membran filtre ve çelik filtre sistemi (Sartorius, Almanya) kullanılarak yoğunlaştırıldı. Biyofilm örnekleri iki dakika "stomacher" (IUL Instruments 120 sn/50 hz) cihazında tutuldu ve vortekslendi. Süspansiyonun bir kısmı \%50 etanol eklenerek (1/1) FISH yönteminde kullanılmak üzere $-20^{\circ} \mathrm{C}^{\prime}$ de saklandı, kalan kısmı kültür yönteminde kullanıldı. Örneklerdeki SYA'nın kültürü için, önceden $200 \mu$ l cansız E.coli süspansiyonu besiyerine 
yayıldı, besleyici değeri olmayan nonnutrient agar (NNA) kullanıldı, $28^{\circ} \mathrm{C}^{\prime}$ de 3-10 gün inkübe edildi. Tüm ekimler üç kez tekrar edilerek çalışıldı. Amiplerin trofozoit ve kist şekilleri günlük olarak ışık mikroskobunda (Olympus, Japonya) (100x) incelendi ${ }^{11}$. Ayrıca, $28^{\circ} \mathrm{C}^{\prime}$ de üreyen SYA'nın termotoleran aktivitelerinin araştırılması için yüzeyine taze $E$.coli ekilmiş NNA besiyerine pasajları yapılarak $44^{\circ} \mathrm{C}^{\prime}$ de üç gün inkübe edildi ${ }^{12}$.

Legionella kültürü: Laboratuvara getirilen su örnekleri Legionella cinsi bakterilerin analizi amacıyla $142 \mathrm{~mm}$ çaplı, $0.2 \mu \mathrm{m}$ por çaplı naylon membran filtreler (SartoriusSartolon, Almanya) kullanılarak çelik filtre sisteminden süzüldü. Biyofilm örnekleri iki dakika "stomacher" (IUL Instruments 120 sn/50 hz) cihazında tutuldu ve vortekslendi. Bu süspansiyonun bir kısmı kültür yönteminde kullanıldı, bir kısmı \%50 etanol eklenerek (1/1) FISH yönteminde kullanılmak üzere $-20^{\circ} \mathrm{C}^{\prime}$ de saklandı. Legionella cinsi bakterilerin kültürü için, örnekler asit $(\mathrm{HCl}-\mathrm{KCl})$ ve ısı ile $\left(50^{\circ} \mathrm{C}\right.$, 30 dakika) muamele edildikten sonra glisin-vankomisin-polimiksin-sikloheksimid (GVPC) eklenmiş "buffered charcoal yeast ekstract (BCYE)" besiyerine ekimi yapılarak $37^{\circ} \mathrm{C}^{\prime}$ de 14 gün inkübe edildi. Tüm ekimler üç kez tekrar edilerek çalışıldı. İnkübasyon sonrası üreyen şüpheli kolonilerden Gram boyama, triptik soy agarda üreme özellikleri incelendi, serolojik tanımlama Legionella lateks aglütinasyon kiti kullanılarak (Oxoid, İngiltere) gerçekleştirildi ${ }^{13-16}$.

\section{Floresan İn Situ Hibridizasyon Yöntemi}

$-20^{\circ} \mathrm{C}^{\prime}$ de saklanmış olan örnekler oda sıcaklığına getirildikten sonra, Legionella ve Acanthamoeba cinsi SYA'nın varlığı açısından FISH yöntemiyle analiz edildi ${ }^{17-19}$. Hem su hem de biyofilm örnekleri, Legionella bakterileri için \%4, Acanthamoeba cinsi için \%2 paraformaldehit (PFA) ile $+4^{\circ} \mathrm{C}^{\prime}$ de bir gece fikse edildi. Legionella için $13000 \mathrm{rpm}$ 'de, Acanthamoeba için 8230 rpm'de 1xPBS ile üç kez santrifüj (Beckman, ABD) edilerek yıkandı. Yıkama işleminden sonra $10 \mu$ örnek alınarak, teflon kaplı kuyucuklu lama koyuldu, kuruması beklendi ve dehidrasyon amacıyla yükselen alkol serilerinde (\%50, \%80, \%96) üçer dakika $46^{\circ} \mathrm{C}^{\prime}$ de bekletildi. Süre sonunda kuyucuklara \%20 formamit içeren hibridizasyon tamponu (0.9 M NaCl, $20 \mathrm{mM}$ Tris/HCl, \%0.01 SDS) ve spesifik floresan boya ile işaretli uygun problar ilave edildi. Bu problar (Integrated DNA Technologies Inc, ABD) Acanthamoeba cinsi SYA, Legionella cinsi, L.pneumophila serogroup 1 için sırasıyla

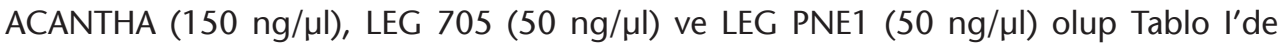
gösterilmiştir. Tüm lamlar, $46^{\circ} \mathrm{C}^{\prime}$ de 24 saat karanlık ve nemli ortamda inkübe edildikten sonra kuyucuklara $2 \mu \mathrm{l}$ DNA bağlama boyası 6-diamino-2-fenilindol (DAPI) eklenerek 30 dakika daha bekletildi. Süre sonunda lamlar, yıkama tamponu (20 mM Tris/ $\mathrm{HCl}, \mathrm{pH}$ 7.6, \%0.01 sodyum dodesil sülfat, $5 \mathrm{mM}$ EDTA, $160 \mathrm{mM} \mathrm{NaCl}$ ) ile $46^{\circ} \mathrm{C}^{\prime}$ de 15 dakika bekletilerek son yıkama işlemi $+4^{\circ} \mathrm{C}^{\prime}$ de 10 dakika bidistile su kullanılarak gerçekleştirildi. Lamların kurumasını takiben kuyucuklara $5 \mu$ l "anti-fading" çözeltisi damlatılarak epifloresan mikroskopta (Nikon Eclipse 80i, Japonya) üç kez incelendi. Pozitif kontrol olarak L.pneumophila serogroup 1 ATCC 33152, L.pneumophila serogroup 3 ATCC 33155, A.castellani ATCC 50373 suşları kullanıldı. EUK 516 probu ökaryotlar için pozitif kontrol, NON 338 probu öbakteriler için negatif kontrol olarak kullanıldı (Tablo I). 


\begin{tabular}{|llc|}
\hline \multicolumn{3}{l}{ Tablo I. Hibridizasyon Deneylerinde Kullanılan Floresan Boya ile işaretli Problar } \\
\hline Prob adı & Oligonükleotit prob & Floresan boya \\
\hline ACANTHA & 5'-TTC-ACG-GTA-AAC-GAT-CTG-GGC-C-3' & FAM-5' \\
EUK 516 & 5'-ACC-AGA-CTT-GCC-CTC-C-3' & CY3-5' \\
Leg PNE1 & 5'-ATC-TGA-CCG-TCC-CAG-GTT-3' & CY3-5' \\
Leg 705 & 5'-CTG-GTG-TTC-CTT-CCG-ATC-3' & FAM-5' \\
NON338 & 5'-ACT CCT ACG GGA GGC AGC-3' & FAM-5' \\
\hline FAM: Carboxyfluorescein, CY3: Cyanin 3.
\end{tabular}

\section{İstatistiksel Analiz}

Kültür yöntemiyle araştırılan mikroorganizmaların (TAHB, SYA, Legionella) su ve biyofilm içinde rastlanma oranları analizleri için parametrik yöntemler tercih edildi. Bu amaçla ikili karşılaştırmalar yapıldı ve t-testi kullanıldı.

Su ve biyofilm örneklerindeki Legionella ve SYA araştırılmasında kültür ve FISH yöntemlerinin birbiriyle uyumlu olup olmaması parametrik olmayan tekniklerden biri olan Cohen'in kappa katsayısı (k) vasıtasıyla incelendi.

FISH yöntemiyle araştırılan Acanthamoeba cinsi mikroorganizmaların, su ve biyofilm içindeki miktarlarının farklı olup olmadığını belirlemek amacıyla parametrik olmayan tekniklerden Wilcoxon Signed Rank (WSR) testi gerçekleştirildi.

Değerlendirme kriteri olarak belirlenen üç kriter (havuz suyu sıcaklıkları, serbest klor ve pH değerleri) bazında havuzların açık ya da kapalı olma durumunun herhangi bir farklılığa neden olup olmadığı parametrik olmayan tekniklerden birisi olan Mann-Whitney U testi tercih edilerek kullanıldı.

Havuz sularında ölçülen farklı klor düzeylerine (normal, yüksek, düşük) göre Legionella ve SYA'ya rastlama (pozitif) ve rastlamama (negatif) durumu parametrik olmayan tekniklerden bir diğeri olan Wilcoxon işaretli sıralar testi kullanılarak analiz edildi.

\section{BULGULAR}

Kültür yöntemine göre; su örneklerinin 23 (\%92)'ünde TAHB, 4 (\%16)'ünde SYA saptanmış, fakat hiçbirinde Legionella cinsi bakterilere rastlanmamıştır (Tablo II, Resim 2). İzole edilen SYA'nın birinin $44^{\circ} \mathrm{C}^{\prime}$ de üreme yeteneği sayesinde termotoleran aktiviteye sahip izolat olduğu saptanmıştır. Aynı örneklerin FISH yöntemine göre incelenmesi sonucunda 7 (\%28)'sinde SYA, 6 (\%24)'sında Legionella cinsi bakteriler tespit edilmiştir (Tablo II, Resim 3).

Kültür yöntemine göre; biyofilm örneklerinin 21 (\%84)'inde TAHB, 2 (\%8)'sinde SYA, 1 (\%4)'inde Legionella cinsi bakteriler saptanmıştır. Aynı örneklerin FISH yöntemine göre incelenmesi sonucunda 6 (\%24)'sında SYA, 7 (\%28)'sinde Legionella cinsi bakteriler tespit edilmiştir. 
İstanbul'daki Yüzme Havuzu Suları ve Biyofilm Örneklerinde Legionella ve Serbest Yaşayan Amiplerin Görülme Sıklığının Farklı Yöntemlerle Araştıııması

\begin{tabular}{|lcccc|}
\hline \multicolumn{5}{|c|}{ Tablo II. Incelenen Havuzlarda Kültür ve FISH Yöntemine Göre Saptanan Mikroorganizmaların Dağı̆ımı } \\
\cline { 2 - 5 } & Sültür & \multicolumn{3}{c|}{ FISH } \\
\hline TAHB & Biyofilm (\%) & Su (\%) & Biyofilm (\%) \\
SYA & 92 & 84 & - & - \\
Legionella spp. & 16 & 8 & 28 & 20 \\
\hline TAHB: Toplam aerobik heterotrofik bakteriler, SYA: Serbest yaşayan amipler. & 24 & 28 \\
\hline
\end{tabular}
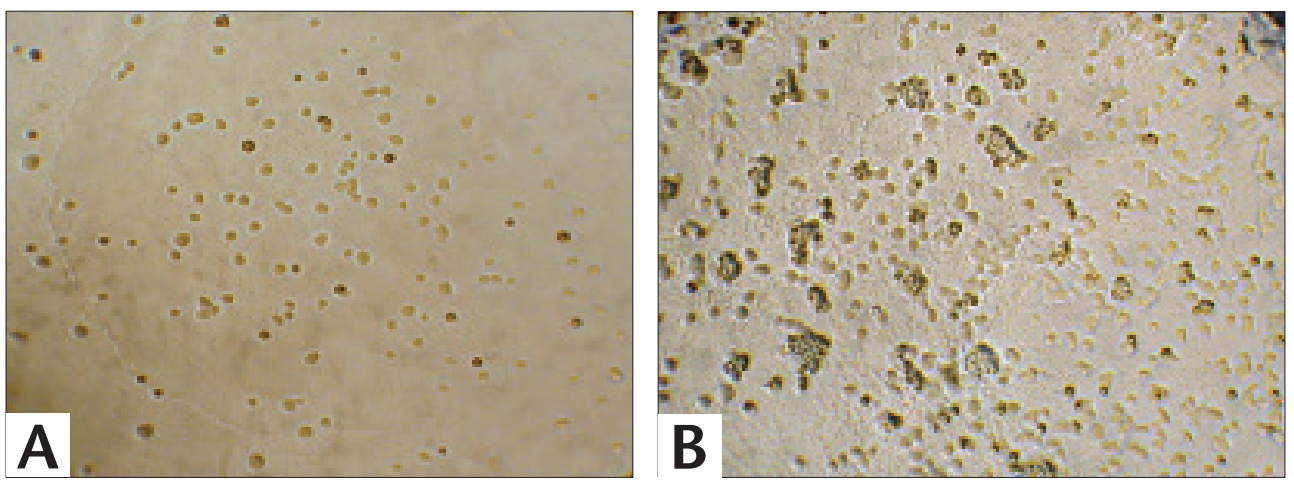

Resim 2. NNA besiyerinde üremiş serbest yaşayan amiplerin ışık mikroskobundaki görüntüsü (x100). A. Trofozoit, B. Kist.
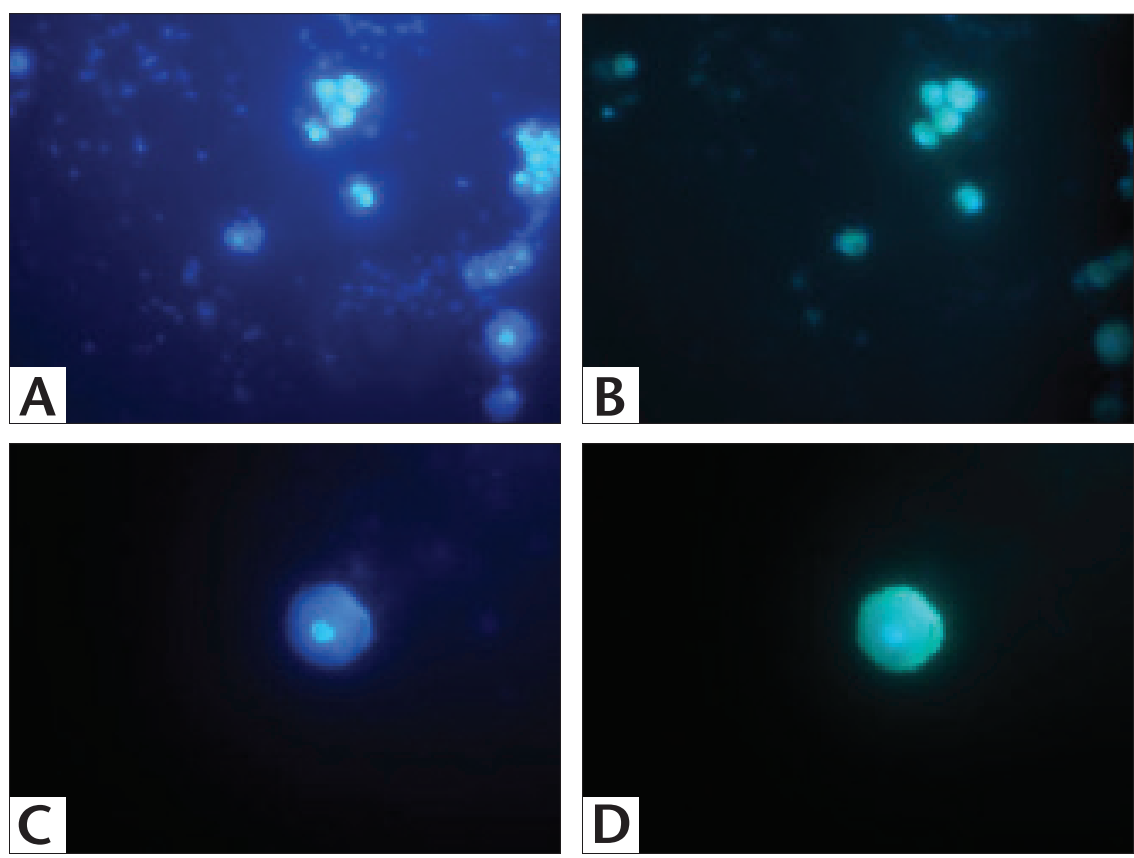

Resim 3. Acanthamoeba'nın epifloresan mikroskoptaki görüntüleri. A. ACANTHA-DAPI (500x), B. ACANTHA-FAM (500x), C. ACANTHA-DAPI (1000x), D. ACANTHA-FAM (1000x). 
İstatistiksel analiz sonucunda kültür yöntemiyle araştırılan mikroorganizmaların (TAHB, SYA, Legionella) su ve biyofilm içinde rastlanma oranları arasında bir ilişkinin söz konusu olduğu tespit edilmiş $\left(X^{2}=0.042 ; p \leq 0.05\right)$, bu ilişkinin pozitif ve \%17.4 düzeyinde olduğu saptanmıştır. TAHB ve SYA'ya su örneklerinde biyofilm örneklerindekine göre daha fazla, Legionella cinsi bakterilere ise biyofilm örneklerinde su örneklerindekine göre daha fazla oranda rastlandığı saptanmıştır ( $\mathrm{p} \leq 0.05)$.

Incelenen havuz suyu örneklerinin 5 (\%20)'inde TAHB sayısı, 200 kob/ml'yi aşmıştır. Aynı havuzlara ait biyofilm örneklerindeki TAHB sayısı, $22^{\circ} \mathrm{C}^{\prime}$ deki kültürlerin 4 (\%16)'ünün $37^{\circ} \mathrm{C}^{\prime}$ deki kültürlerin 3 (\%12)'ünün 200 kob/ml'yi aştığı saptanmıştır (Tablo III).

\begin{tabular}{|c|c|c|c|c|c|c|c|}
\hline \multirow[b]{2}{*}{ Havuz no } & \multicolumn{2}{|c|}{$\mathrm{Su}(\mathrm{kob} / \mathrm{ml})$} & \multicolumn{2}{|c|}{$\begin{array}{l}\text { Biyofilm } \\
\left(\mathrm{kob} / \mathrm{cm}^{2}\right)\end{array}$} & \multirow[b]{2}{*}{ Sicaklık $\left({ }^{\circ} \mathrm{C}\right)$} & \multirow[b]{2}{*}{ Serbest klor $(\mathrm{mg} / \mathrm{L})$} & \multirow[b]{2}{*}{$\mathrm{pH}$} \\
\hline & $22^{\circ} \mathrm{C}$ & $37^{\circ} \mathrm{C}$ & $22^{\circ} \mathrm{C}$ & $37^{\circ} \mathrm{C}$ & & & \\
\hline 1 ** & 345 & 280 & 128 & 80 & 8 & 0.15 & 6.8 \\
\hline $2^{* *}$ & 240 & 397 & 218 & 157 & 8 & 0.15 & 6.8 \\
\hline 3 & 57 & 66 & 1 & 0 & 30 & 4 & 7.2 \\
\hline 4 & 0 & 0 & 15 & 59 & 28 & 3 & 6.8 \\
\hline 5 & 0 & 0 & 0 & 0 & 28 & 4 & 6.8 \\
\hline 6 & 3 & 0 & 0 & 1 & 27 & 3 & 6.8 \\
\hline 7 & 166 & 5 & 5 & 1 & 29 & 4 & 7.4 \\
\hline 8 & 30 & 0 & 256 & 275 & 28 & 1.5 & 6.8 \\
\hline 9 & 102 & 16 & 38 & 0 & 28 & 1.5 & 6.8 \\
\hline 10 & 460 & 685 & 525 & 465 & 24 & 0.6 & 6.8 \\
\hline $11^{* *}$ & 163 & 86 & 1 & 0 & 18 & 3 & 6.8 \\
\hline $12^{* *}$ & 28 & 13 & 0 & 15 & 9 & 4 & 7.4 \\
\hline 13 & 60 & 135 & 85 & 14 & 30 & 1.5 & 6.8 \\
\hline $14^{* *}$ & 202 & 345 & 101 & 27 & 8 & 1 & 7.2 \\
\hline $15^{\mathrm{a}}$ & 116 & 53 & 0 & 0 & 27 & 0.30 & 7.4 \\
\hline $16^{\mathrm{a}}$ & 48 & 78 & 36 & 1 & 29 & 1 & 7.4 \\
\hline $17^{* *}$ & 45 & 33 & 1 & 0 & 8 & 1 & 6.8 \\
\hline $18^{\mathrm{a}}$ & 84 & 64 & 0 & 0 & 28 & 1 & 7.2 \\
\hline $19^{\mathrm{a}}$ & 130 & 149 & 77 & 89 & 28 & 0.40 & 7.4 \\
\hline $20^{\mathrm{a}}$ & 117 & 40 & 40 & 56 & 38 & 0.15 & 7.4 \\
\hline $21^{\mathrm{a}}$ & 30 & 26 & 1 & 0 & 28 & 1.5 & 7.4 \\
\hline $22^{\mathrm{a}}$ & 24 & 24 & 0 & 0 & 33 & 1.5 & 7.2 \\
\hline $23^{\mathrm{a}}$ & 24 & 22 & 2 & 1 & 20 & 3 & 6.8 \\
\hline $24^{\mathrm{a}}$ & 22 & 19 & 7 & 5 & 27 & 1.5 & 7.2 \\
\hline 25 & 560 & 370 & 236 & 230 & 29 & 0.60 & 6.5 \\
\hline
\end{tabular}


Incelenen havuz sularında su sıcaklıkları, serbest klor ve $\mathrm{pH}$ değerleri ölçüm aralıkları sırasıyla $8-38^{\circ} \mathrm{C}, 0.15-4 \mathrm{mg} / \mathrm{L}, 6.5-7.4$ olarak tespit edilmiş̧tir (Tablo III). Bu çalışmada, incelenen havuz sularının bu fiziksel ve kimyasal değerleri incelendiğinde en dengeli sonuçların pH değerlerinde, en büyük değişimlerin serbest klor değerlerinde ortaya çıktığı, kapalı havuzların (ortalama $23.37^{\circ} \mathrm{C}$ ) açı havuzlardan (ortalama $9.33^{\circ} \mathrm{C}$ ) daha sıcak olduğu ( $\mathrm{s} \leq$ $0.05)$ saptanmışıtı. Havuz sularında saptanan klor düzeylerindeki artış ile SYA ve Legionella'ya rastlamama durumu arasında (-) yönlü ve anlamlı bir ilişki saptanmıştır $(p \leq 0.05)$.

Kültür yöntemine göre, incelenen su örneklerinin dördünde (Havuz no: 2, 13, 14, 20), biyofilm örneklerinin ikisinde (Havuz no: 10, 20) SYA saptanmıştır (Resim 2). İncelenen örneklerin ACANTHA probu kullanılarak FISH yöntemiyle incelenmesi sonucunda tespit edilen Acanthamoeba cinsi bakterilerin floresan görüntüsü (Resim 3) ve SYA'nın dağılımı (Tablo IV) verilmiştir. Kültür yönteminde tespit edilemediği halde üç su örneğinde (Havuz no: $1,4,10)$ ve üç biyofilm örneğinde SYA tespit edilmiştir $\left(\kappa_{\text {su }}=0.66, \kappa_{\text {biyofilm }}=0.52\right)$.

\begin{tabular}{|c|c|c|}
\hline Havuz no & Su (hücre $/ \mathrm{ml}$ ) & Biyofilm (hücre $/ \mathrm{cm}^{2}$ ) \\
\hline 1 & $32.1 \times 10^{2}$ & $0.36 \times 105$ \\
\hline 2 & $3.56 \times 10^{2}$ & 0 \\
\hline 3 & 0 & 0 \\
\hline 4 & $14.3 \times 10^{2}$ & 0 \\
\hline 5 & 0 & 0 \\
\hline 6 & 0 & 0 \\
\hline 7 & 0 & 0 \\
\hline 8 & 0 & 0 \\
\hline 9 & 0 & 0 \\
\hline 10 & $14.3 \times 10^{2}$ & $0.36 \times 10^{5}$ \\
\hline 11 & 0 & 0 \\
\hline 12 & 0 & 0 \\
\hline 13 & $7.13 \times 10^{2}$ & $0.36 \times 10^{5}$ \\
\hline 14 & $10.7 \times 10^{2}$ & $0.71 \times 10^{5}$ \\
\hline 15 & 0 & 0 \\
\hline 16 & 0 & 0 \\
\hline 17 & 0 & 0 \\
\hline 18 & 0 & 0 \\
\hline 19 & 0 & 0 \\
\hline 20 & $32.1 \times 10^{2}$ & $0.71 \times 10^{5}$ \\
\hline 21 & 0 & 0 \\
\hline 22 & 0 & 0 \\
\hline 23 & 0 & 0 \\
\hline 24 & 0 & 0 \\
\hline 25 & 0 & 0 \\
\hline
\end{tabular}


İncelenen yüzme havuzlarında FISH yöntemi kullanılarak tespit edilen Acanthamoeba cinsi mikroorganizmaların, su (hücre/ml) ve biyofilm (hücre $/ \mathrm{cm}^{2}$ ) içindeki miktarlarının arasında Wilcoxon işaretli sıralar testine göre istatistiksel farklılığa rastlanmamıştır ( $p>$ 0.05).

Örneklerin kültür yöntemine göre incelenmesi sonucunda sadece bir biyofilm örneğinde Legionella cinsi bakteri $\left(200 \mathrm{kob} / \mathrm{cm}^{2}\right)$ saptanmış olduğu halde, Tablo V'te görüldüğü gibi FISH yöntemiyle bu bakteriler altı su ve yedi biyofilm örneğinde tespit edilmiş ve istatistiksel olarak anlamlı bulunmuştur $\left(\kappa_{\text {su }}=0.93, \kappa_{\text {biyofilm }}=0.86\right)$. Bir su ve dört biyofilm örneğindeki bu bakteriler L.pneumophila serogrup 1 olarak tanımlanmıştır.

\begin{tabular}{|c|c|c|c|c|}
\hline \multirow[b]{2}{*}{ Havuz no } & \multicolumn{2}{|c|}{ Su (hücre/ml) } & \multicolumn{2}{|c|}{ Biyofilm (hücre/cm²) } \\
\hline & LPS 1 & LEG & LPS 1 & LEG \\
\hline 1 & 0 & 0 & & $0.36 \times 10^{5}$ \\
\hline 2 & 0 & $17.8 \times 10^{2}$ & 0 & $11 \times 10^{5}$ \\
\hline 3 & 0 & $0.36 \times 10^{2}$ & 0 & 0 \\
\hline 4 & 0 & 0 & 0 & 0 \\
\hline 5 & 0 & 0 & 0 & 0 \\
\hline 6 & 0 & 0 & 0 & 0 \\
\hline 7 & 0 & 0 & 0 & 0 \\
\hline 8 & 0 & 0 & 0 & 0 \\
\hline 9 & 0 & 0 & 0 & 0 \\
\hline 10 & 0 & $0.59 \times 10^{2}$ & 0 & $0.36 \times 10^{5}$ \\
\hline 11 & 0 & 0 & 0 & 0 \\
\hline 12 & 0 & 0 & $0.36 \times 10^{5}$ & $8.9 \times 10^{5}$ \\
\hline 13 & 0 & $0.48 \times 10^{2}$ & 0 & 0 \\
\hline 14 & $3.65 \times 10^{2}$ & $8.32 \times 10^{2}$ & $4.6 \times 10^{5}$ & 0 \\
\hline 15 & 0 & 0 & 0 & 0 \\
\hline 16 & 0 & 0 & 0 & 0 \\
\hline 17 & 0 & 0 & 0 & 0 \\
\hline 18 & 0 & 0 & 0 & 0 \\
\hline 19 & 0 & 0 & 0 & 0 \\
\hline 20 & 0 & 0 & 0 & 0 \\
\hline 21 & 0 & $0.12 \times 10^{2}$ & $0.36 \times 10^{5}$ & 0 \\
\hline 22 & 0 & 0 & $0.71 \times 10^{5}$ & $1.8 \times 10^{5}$ \\
\hline 23 & 0 & 0 & 0 & 0 \\
\hline 24 & 0 & 0 & 0 & 0 \\
\hline 25 & 0 & 0 & 0 & 0 \\
\hline
\end{tabular}

LPS1: Legionella pneumophila serogrup 1, LEG: Legionellaceae. 


\section{TARTIŞMA}

Çeşitli ülkelerde yüzme havuzlarının mikrobiyolojik açıdan kabul edilen standart değerleri arasında farklılıklar bulunmaktadır. Örneğin TAHB sayısı $20^{\circ} \mathrm{C}$ ve $36^{\circ} \mathrm{C}$ için Almanya standartlarında $\leq 100 \mathrm{kob} / \mathrm{ml}$, İtalya standartlarında $\left(36^{\circ} \mathrm{C}\right) \leq 200 \mathrm{kob} / \mathrm{ml}$, İngiltere standartlarında $\left(36^{\circ} \mathrm{C}\right)<10 \mathrm{kob} / \mathrm{ml}$, Avustralya standartlarında $\leq 100 \mathrm{kob} / \mathrm{ml}$ olarak belirlenmiştir ${ }^{20}$. Ülkemizde T.C. Sağlık Bakanlığı tarafından 2011'de yayımlanan genelgede $37^{\circ} \mathrm{C}^{\prime}$ de 24 saat inkübasyon sonucu TAHB sayısının $\leq 200 \mathrm{kob} / \mathrm{ml}$ olması gerektiği belirtilmiştir². Yüzme havuzlarının temizliğinin/dezenfeksiyonunun sağlanması ve bunun anlaşılması için yapılan denetimler, mikrobiyolojik standart değerlerinin sağlanması ve dolayısıyla havuzu kullananların sağlığı açısından oldukça önemlidir. Bu çalışmada incelenen havuz sularının temizliklerinin/dezenfeksiyonlarının periyodik olarak yapıldığı bilgisine dolaylı yoldan erişilmiştir. İncelenen ve Bakırköy Belediyesi Çevre Koruma ve Kontrol Biriminin denetiminde olduğu öğrenilen dokuz yüzme havuzundan örnek alım zamanımız bu kurumun denetim zamanıyla eş zamanlı olarak gerçekleştirilmiş ve bu havuz sularının tümünün TAHB açısından T.C. Sağlık Bakanlığı tarafından belirtilen standartlara uygun olduğu saptanmıştır. Bu sonuçlar, havuz sularındaki TAHB sayısının kontrol altında tutulması için ülkemizde otoriteler tarafından yapılan periyodik kontrollerin gerekliliğini ve amacına ulaştığını göstermektedir. Diğer işletmelerde denetimlerin yapılması hakkında bilgiye ulaşılamamakla birlikte, çalışmada incelenen havuz sularının \%80'inin TAHB açısından riskli olmadığı saptanmıştır (Tablo III). Öte yandan biyofilm örneklerine ait standart değerler konusunda herhangi bir yönetmelik olmamasına rağmen, aynı havuzlardan alınan biyofilm örneklerinin incelenmesinden elde edilen sonuçlara göre $22^{\circ} \mathrm{C}^{\prime}$ de inkübe edilen örneklerin $\% 16^{\prime}$ sında, $37^{\circ} \mathrm{C}^{\prime}$ de inkübe edilen örneklerin \%12'sinde 200 kob/ml sınıını aştığı bulunmuştur. Çalışmamıza benzer olarak, Avrupa, Amerika ve Avustralya'da yapılan çalışmalarda da ülkelerin belirlediği standart değerlerin üstünde TAHB'lerin varlığı saptanmıştır ${ }^{20-22}$.

Önceki çalışmamızda ${ }^{23}$ yüzme havuzlarında kullanılan klor konsantrasyonlarının havuzlardan izole edilen SYA için inhibe edici etki göstermediği tespit edilmiştir. Bu nedenle, SYA ve Legionella cinsi bakterilerin (özellikle lejyoner hastalığı etkeni olan L.pneumophila'nın) aynı su ortamında birlikte bulunması, risk grubundaki bireylerin sağıı̆ını ciddi ölçüde tehdit edebilmektedir. Bu çalışmada üç su (Havuz no: 2, 13, 14) ve bir biyofilm örneğinde (Havuz no: 10) hem SYA hem Legionella cinsi bakteriler tespit edilmiştir (Tablo IV,V). Yüzme havuzlarında bu iki mikroorganizmanın varlığının tespit edilmesi durumunda su kontrol önlemlerinin yeniden gözden geçirilmesi, örneğin etkili dezenfektan konsantrasyonunun yeniden belirlenmesi gibi önlemlerin alınması mümkün olacaktır. Ayrıca, çalışmamızda üç su (1, 4, 20) ve iki biyofilm (örnek no: 13, 20) örneğinde Legionella cinsi bakteriler bulunmadığı halde Acanthamoeba cinsi amiplerin saptanmış olması bu örneklerde Legionella cinsi bakterilerin bu amipler içerisinde saklı olma ihtimalini akla getirmektedir. Konunun aydınlığa kavuşturulması, ülkemiz havuz su/biyofilm örneklerinden izole edilen amip hücreleri içerisinde bu bakterilerin varlığı/tanımlanmasını sağlayacak olan yeni çalışmaların gerçekleştirilmesiyle mümkün olacaktır. 
TAHB'lerin yanı sıra, SYA'larda pek çok su ortamında yaşayabildiği gibi yüzme havuzlarında da yaşayıp çoğalarak sağlık riski oluşturabilirler. 1960'lardan bu yana yapılan araştırmalar, SYA'ların bazı suşlarının insanlar için patojenik olabileceğini göstermiştir. Örneğin klorlanmamış havuzlarda yüzerken veya kontakt lens takarken insanlarla yakın temas halindeyken hastalık oluşturabilirler. Acanthamoeba cinsi SYA özellikle immün sistemi baskılanmış insanlarda, santral sinir sisteminde ortaya çıkan, granülomatöz amibik ensefalit (GAE) etkenidir. Öte yandan, Acanthamoeba keratiti sağlıklı bireylerde kontamine suya maruz kalma ile ilişkili olabilmektedir ${ }^{7}$. Ayrıca bu mikroorganizmalar, hem dirençli kist formları sayesinde kendilerini hem de Legionella cinsi bakterileri (ve diğer bazı prokaryotlara) üzerlerinde konak olarak bulundurmaları nedeniyle havuz sularına uygulanan dezenfektanlardan koruyabilmektedir ${ }^{5-7}$. Çalışmamızda havuz suyu örneklerinin yedisinde, biyofilm örneklerinin beşinde SYA'ya rastlanmış olması ve bir izolatın potansiyel patojen (termotoleran) ${ }^{12,24}$ olarak saptanması bu havuzların sağlık açısından riskli olduğunu akla getirmektedir. Nitekim, son yıllarda yapılan çalışmalarda ülkemizin doğal sularında da patojen SYA'nın varlığı gösterilmiştir ${ }^{25,26}$. Bu tip patojen amipleri içeren doğal suların havuz suyu olarak kullanılma ve amiplerin uygulanan dezenfektan konsantrasyonlarına dirençli olma olasılıkları nedeniyle, havuzları kullanan yüzücülerin sağlığının tehdit altında olduğu düşünülmekte ve yapılacak çalışmaların artırılması gerekmektedir.

Gerek su gerekse biyofilm örneklerindeki SYA'nın varlığının tespiti için kültür ve FISH yöntemlerinin kullanılması uygun olabilir. Kültür yönteminde morfolojinin tanımlama için yanıltıcı olması, fazla emek ve zamana ihtiyaç göstermesi, hücre sayısının saptanamaması vb. dezavantajlarını FISH yöntemi ile ortadan kaldırmak mümkündür ${ }^{11}$. Ancak bu mikroorganizmaların izole edilerek patojenitelerinin, fizyolojik özelliklerinin ve bakterilerle olan ilişkilerinin araştırılabilmesi için mutlaka kültür yöntemine ihtiyaç duyulmaktadır. Tüm bu nedenlerden dolayı SYA'nın varlığı/patojenitesi çalışmalarında yüzme havuzlarının hem su hem de biyofilm örneklerinin, hem kültür hem de FISH yöntemi kullanılarak analiz edilmesi gerekmektedir. SYA tespit edilmesi durumunda etkin dezenfeksiyon yöntemlerinin uygulanması sayesinde konaklık ettiği patojen bakterilerin de ortadan kaldırılması mümkün olacak ve halk sağlığı korunmuş olacaktır.

Çalışmamızın istatistiksel analiz sonuçları ( $\mathrm{p} \leq 0.05)$, yüzme havuzlarında gerek SYA gerekse Legionella cinsi bakterilerin kültür yöntemiyle tespiti için hem su hem de biyofilm örneklerinin incelenmesinin bilimsel gereksinim olacağını düşündürmektedir (Tablo II). Bulgularımıza benzer olarak, Wisconsin'deki havuzları kullanan otel misafirleri arasında bir dizi hastalığa sebep olan Legionella micdadei'nin havuz suyu örneklerinden kültür yapılmasıyla izole edilemediği halde havuz filtresinden (150 kob/ml) izole edildiği bildirilmiştir ${ }^{27}$. Legionella cinsi bakterilerin, yüzme havuzu sularında saptanmamasına karşın, zamanla biyofilmde ve aynı havuzlarda yaşadığını tespit ettiğimiz SYA içerisinde de çoğalması mümkün olabilmektedir. Böylece, dezenfektanlara direnç ortaya çıkabil- 
mektedir ${ }^{24}$, bu amiplerin parçalanmasıyla da bakteri artan oranlarda havuz suyuna geçebilmektedir. Tüm bunların sonucunda havuzda yüzen insanların sağıı̆ı büyük tehdit altına girebilir. Çalışmamızda kültür yöntemiyle yalnız bir havuza ait biyofilm örneğinde Legionella cinsi bakteriler tespit edilebildiği halde FISH yönteminin kullanılmasıyla altı su ve yedi biyofilm örneğinde saptanmış olması bu bakterilerin tespitinde FISH yönteminin daha üstün bir yöntem olabileceğini düşündürmektedir $\left(\kappa_{\text {su }}=0.93, \kappa_{\text {biyofilm }}=\right.$ 0.86). Bu bakterilerin, varlığının kültür yöntemiyle tespit edilememesinin nedeni, canlı fakat (üretilemeyen faza girebilmeleriyle açıklanabiliir ${ }^{28}$. Nitekim Steinert ve arkadaşları, L.pneumophila Philadelphia I JR 32 suşunu steril musluk suyuna ekerek bakteri sayısındaki azalmayı inceledikleri çalışmalarında ${ }^{29}$, durgun su içinde, oda sıcaklığında, karanlık ortamda 125 gün inkübasyondan sonra kültür yöntemiyle izolasyon gerçekleştiremedikleri halde, FISH yöntemiyle inceleme sonucunda bu bakterileri tespit ettiklerini bildirmişlerdir. Bununla birlikte, tıpkı SYA'da olduğu gibi Legionella cinsi bakterilerin doğru izole edilebilmesi ve daha sonraki çalışmalarda kullanılabilmesi için kültür yönteminin de kullanılması gereklidir.

Yüzme havuzu sularının pH, serbest klor değeri ve sıcaklığı mikroorganizmaların varlığını etkileyebilecek olan parametrelerden olup normal değerleri T.C. Sağlık Bakanlığı tarafından 6 Mart 2011 tarihinde Resmi Gazete'de yayımlanan yönetmelikte belirtilmiştir. Bu çalışmada incelenen havuz sularının bu fiziksel ve kimyasal değerleri incelendiğinde (Tablo III) en dengeli sonuçların pH değerlerinde, en büyük değiş̧imlerin serbest klor değerlerinde ortaya çıktığı, kapalı havuzların (ortalama $23.37^{\circ} \mathrm{C}$ ) açık havuzlardan (ortalama $\left.9.33^{\circ} \mathrm{C}\right)$ daha sıcak olduğu $(p \leq 0.05)$ saptanmıştır. İncelenen 19 kapalı havuzun 10'unun su sıcaklığının T.C. Sağık Bakanlığınca belirlenen mevzuata uygun olduğu, açık havuzların tümünün bu sınırların altında olduğu saptanmıştır. Termotoleran (potansiyel patojen) SYA izolatı bu sınırların dışında kalan $38^{\circ} \mathrm{C}$ su sıcaklığına sahip kapalı termal havuzda tespit edilmiştir. Çalışmamızda incelenen 25 havuzun 11'inde normal, yedisinde düşük, yedisinde yüksek düzeyde serbest klor değeri tespit edilmiştir. TAHB sayıları $\leq 200 \mathrm{kob} / \mathrm{ml}$ olan havuzların 10'unda serbest klor değerleri mevzuata uygun değerde, yedisinde oldukça yüksek değerde (3-4 mg/L), üçünde oldukça düşük değerde ölçülmüştür. Legionella cinsi bakteriler, mevzuata uygun serbest klor değerine sahip olmasına rağmen dört havuzda, yüksek değere sahip olmasına rağmen iki havuzda tespit edilmiştir. SYA ise mevzuata uygun serbest klor değerine sahip olmasına rağmen iki havuzda, yüksek değere sahip olmasına rağmen bir havuzda tespit edilmiştir. Incelenen tüm havuz sularının $\mathrm{pH}$ değerleri mevzuata uygun bulunmuştur. Legionella ve SYA'nın aynı anda tespit edildiği havuz sayılarının, düşük serbest klor düzeyine sahip havuzlardan, mevzuata uygun ve daha yüksek serbest klor düzeyine sahip havuzlara gidildikçe azaldığı saptanmışır ( $p \leq 0.05$ ). Yüksek serbest klor düzeyinin $(3 \mathrm{mg} / \mathrm{L})$, Legionella ile kontamine olmuş su sistemlerinde uzun süre (2-24 saat) uygulanması bu bakterinin sebep olduğu kontaminasyonu ortadan kaldırmak için kullanıldığı bilinmektedir. Ancak bu doz, SYA kistlerine etkili olmayabilir, insan sağlığı açısından da riskli ve 
rahatsızlık vericidir ${ }^{4,5,23,30}$. Bu bilgiler ışığında bu çalışma yüzme havuzu sularının fiziksel ve kimyasal parametreler açısından denetlenmesinin gerekli olduğunu bir kez daha ortaya koymuştur. Yüzme havuzlarında mevcut patojen mikroorganizmaların üremelerine engel olacak şekilde uygun eradikasyon ve dezenfeksiyon yöntemlerinin seçilmesi, yüzücülerin sağlığı açısından oldukça önemlidir. Havuzlardaki mikroorganizmaların üremesi üzerine etkisi olabileceği düşünülen ve araştırılmış parametrelere (su sıcaklığı, pH ve serbest klor) ek olarak diğer faktörlerin de (havuzların kullanım sıklığı, temizlik şekli/sıklığı, havuz içi malzemelerin cinsi/biyofilm açısından uygun olup olmadığı vb.) araştırılacağı, birlikte değerlendirileceği resmi kurumlar arası protokollere dayalı yeni çalışmalara ihtiyaç duyulmaktadır.

Bu çalışma ülkemizde yüzme havuzlarında Legionella cinsi bakteriler ve SYA'nın varlığını ortaya çıkartan ilk çalışmadır. Elde edilen bilgiler ışığında İstanbul'da özellikle belediye kontrolü altında bulunan yüzme havuzlarının TAHB açısından riskli olmadığı, sağlık kriterlerine uygun olduğu görülmüştür. Ancak bu mikroorganizmaların dışında yüzme havuzlarımızda varlığı bu çalışma ile kanıtlanmış olan Legionella cinsi bakteriler (özellikle L.pneumophila serogrup 1) ve SYA'nın da halk sağlığı açısından çok önemli olduğu unutulmamalıdır. Bu mikroorganizmaların varlığını/çoğalmasını etkileyen tüm faktörleri değerlendirmek amacıyla ve daha fazla sayıda yüzme havuzlarını içeren kapsamlı çalışmaların gerçekleştirilmesi, bu mikroorganizmaların çoğalmalarına karşı önlemlerin alınması açısından gerekli olduğu düşünülmektedir.

\section{TEŞEKKÜR}

İstatistiksel analizlerde yardımlarını esirgemeyen İstanbul Üniversitesi İstatistik Uygulama ve Araştırma Merkezi Müdürü Doç. Dr. Haluk Zülfikâr'a teşekkür ederiz.

\section{ÇIKAR ÇATIŞMASI}

Yazarlar bu makale ile ilgili herhangi bir çıkar çatışması bildirmemişlerdir.

\section{KAYNAKLAR}

1. Donlan RM. Biofilms: microbial life on surfaces. Emerg Infect Dis 2002;8(9):881-90.

2. Yüzme Havuzlarının Tabi Olacağı Sağlık Esasları Hakkında Yönetmelik. Resmi Gazete Tarihi: 06.03.2011 Resmi Gazete Sayısı: 27866 [www.mevzuat.gov.tr] (Erişim tarihi: 10.10.2019).

3. Umumi Kullanıma Açık Yüzme ve Terapi Havuz Tesisleri için Kurallar. 28 Şubat 2015 [www.uhe.org.tr] (Erişim tarihi: 10.10.2019).

4. Yavuz Cl. Su kaynaklı bir hastalık olarak lejyoner hastalığı ve çevresel sürveyans. Türk Mikrobiyol Cem Derg 2018;48(4):211-27.

5. Cervero-Arago S, Rodriguez-Martinez S, Puertas-Bennasar A, Araujo RM. Effect of common drinking water disinfectants, chlorine and heat, on free Legionella and amoebae-associated Legionella. Plos One 2015;10(8):1-18.

6. Molmeret M, Horn M, Wagner M, Santic M, Abu Kwaik Y. Amoeba as training grounds for intracellular bacterial pathogens. Appl Environ Microbiol 2005;71(1):20-8. 
7. Scheid P. Free-living amoebae as human parasites and hosts for pathogenic microorganisms. Proceedings 2018;2(692):1-11.

8. Yılmaz Ş. İçme kullanma suyu denetimi, pp: 71-81. In: Oğuz Z, Evci D, Özdemir M, Şentürk Ş, Aycan, S (eds), Turizm Sağlığı Eğitimi Kitabı, T.C. Sağlık Bakanlığı Temel Sağlık Hizmetleri Genel Müdürlüğü. 2001, Ankara.

9. Zeybek Z, Doğruöz Güngör N, Türetgen İ. Investigation of heterotrophic bacteria, Legionella and free-living amoeba in cooling tower samples by FISH and culture methods. Eur J Biol 2017;76(1):7-13.

10. HPA, W 22. Enumeration of viable micro-organisms: aerobic colony count by membrane filtration method. National standard method, 2007: W 22, Issue 1.

11. HPA, W 17. Isolation and identification of Acanthamoeba species. National standard method 2004 ; Issue 2.

12. Wannasan A, Chaiwong P, Bunchoo M, Morakote N. Occurence of thermotolerant Naegleria and Acanthamoeba in some natural water sources in Chiang Mai. Chiang Mai Med J 2009;48(3):117-24.

13. HPA, BSOP ID 18. National standard method: Identification of Legionella species. National standard method, 2007.

14. HPA, W 12 Detection and enumeration of Legionella species by filtration and centrifugation. National standard method, 2006.

15. HPA, W15 Detection and enumeration of Legionella species in biofilms and sediments. National standard method 2006; Issue 1.

16. ISO Water quality-detection and enumeration of Legionella, 1998:11731.

17. Stothard DR, Hay J, Schroeder-Diedrich JM, Seal DV, Byers TJ. Fluorescent oligonucleotide probes for clinical and environmental detection of Acanthamoeba and the T4 18S rRNA gene sequence type. J Clin Microbiol 1998;37(8):2687-93.

18. Grimm D, Merkert H, Ludwig W, Schleifer KH, Hacker J, Brand BC. Specific detection of Legionella pneumophila: construction of a new 16S rRNA-targeted oligonucleotide probe. Appl Environ Microbiol 1998;64(7):2686-90.

19. Manz W, Amann R, Szewzyk R, Szewzyk U, Stenström TA, Hutzler P, et al. In situ identification of Legionellaceae using16S rRNA targeted oligonucleotide probes and confocal laser scanning microscopy. Microbiology 1995;141(Pt 1):29-39.

20. Leoni E, Legnani P, Guberti E, Masotti A. Risk of infection associated with microbiological quality of public swimming pools in Bologna, Italy. Public Health 1999;113(5):227-32.

21. Esterman A, Roder DM, Cameron AS, Robinson BS, Walters RP, Lake JA, et al. Determinants of the microbiological characteristics of South Australian swimming pools. Appl Environ Microbiol 1984;47(2):3258.

22. Keswick BH, Gerba CP, Goyal SM. Occurrence of enteroviruses in community swimming pools. AJPH 1981;71(9):1026-30.

23. Zeybek Z, Demir B, Üstüntürk-Onan M. Unnoticed microorganisms in disinfection of swimming pools: freeliving amoeba. Fresenius Environ Bull 2017;26(12):7651-7.

24. Marciano-Cabral F, Cabral G. Acanthamoeba spp. as agents of disease in humans. Clin Microbiol Rev 2003; 16(2):273-307.

25. Yazar S, Gürbüz E, Sönmez MF, Çetinkaya Ü, Kuk S. Investigation of potentially pathogenic free-living amoebae and their in vivo pathogenicity in water supplies of Turkey. Mikrobiyol Bul 2019;50(3):449-59.

26. Özçelik S, Coşkun KA, Yünlü Ö, Alim A, Malatyalı E. The prevalance, isolation and morphoytping of potentially pathogenic free living amoeba from tap water and environmental water sources in Sivas. Turkiye Parazitol Derg 2012;36(4):198-203.

27. Fields BS, Haupt T, Davis JP, Arduino MJ, Miller PH, Butler JC. Pontiac fever due to Legionella micdadei from a whirlpool spa: possible role of bacterial endotoxin. J Infect Dis 2001;184(10):1289-92. 
28. Dietersdorfer E, Kirschner A, Schrammel B, Ohradanova-Repic A, Stockinger H, Sommer R, et al. Starved viable but non-culturable (VBNC) Legionella strains can infect and replicate in amoebae and human macrophages. Water Res 2018;15(141):428-38.

29. Steinert M, Emody L, Amann R, Hacker J. Resuscitation of viable but nonculturable Legionella pneumophila Philadelphia JR32 by Acanthamoeba castellanii. Appl Environ Microbiol 1997;63(5):2047-53.

30. Vural T. Legionella infeksiyonları. Ankem Derg 2014;28(2):167-76. 